\title{
Study of Coordination on Protection Relay in High Voltage Transmission 150 kV (Payakumbuh - Koto Padang, West Sumatra)
}

\author{
Zulkarnaini Zulkarnaini ${ }^{1}$, Muhammad Rizki $^{2}$ \\ ${ }^{1}$ Lecturer of Electrical Engineering Department, Padang Institute of Technology, 91944 Nanggalo Padang, Indonesia \\ ${ }^{2}$ Student of Electrical Engineering Department, Padang Institute of Technology, 91944 Nanggalo Padang, Indonesia
}

\begin{abstract}
The disturbance of the high voltage transmission can be caused by a short circuit, overload, lightning surge, and other natural disturbances. That disturbance can lead to disruption of the distribution of electricity and damage to the electric power system installation equipment. A reliable protection system that can identify the disturbance quickly and also can securing affected parts of the system from other parts that can still operate normally are needed. Protection system operation may fail due to various factors; therefore, in addition to primary protection required backup protection that can work as primary protection fails to work. Distance relays can be used as primary protection as well as remote backup protection on high-voltage transmission. While overcurrent relay (OCR) and ground fault relay (GFR) is used as a local backup if distance relay failed to work. This research conducted a study of protection relays coordination for primary protection or backup protection on the high-voltage transmission that connects to Payakumbuh substation and Koto Panjang substation. Coordination is done by calculating the distance relay settings that use as primary protection as well as remote backup protection relay settings and calculating the overcurrent and ground fault relay that used as local backup protection. From the calculation, we get setting time to coordinate distance relay, overcurrent relay, and ground fault relay. Setting time was conducted to the first zone of the distance relay within $0 \mathrm{sec}$, and the second zone within $0.4 \mathrm{sec}$ and third zone within $1.2 \mathrm{sec}$. For overcurrent relay and ground fault relay use time delay 1 second where the value is above the value that used in the second zone of distance relay. Distance relay can be coordinated with the auto-reclose relay to close the circuit breaker automatically sometime after a temporary disturbance. Setting that use to auto reclose relay is dead time 1 second and reclaim time 40 second. The coordination between the distance relay with auto-reclose relay can improve the quality of distribution of electrical energy.
\end{abstract}

\section{Introduction}

Electrical energy is a primary requirement for everyone. It uses to distribute electricity from generating centers to the consumers using transmission systems. High Voltage Transmission is one of electric power transmission that plays a very important role in maintaining the quality and reliability of power systems, which is often disturbed. Disturbance can be a form of short circuit, overload, lightning surge, typhoon, bad weather, and others. Such disturbance may result in disruption of continuity of operation and damage to the electrical system [Arismunandar, A. Susumu Kuwahara. 2004]. Electrical protection systems can be failed by operation due to various factors. To anticipate the failure, it is needed the backup protection.

High-Voltage air passages use distance relays as primary protection and have local backup protection as well as remote backup protection. Local backup protection systems use Over Current Relay (OCR) and Grund Fault Relay (GFR), while remote backup protection uses distance relay second zones from other substations. In order to work selectively, the primary protection and backup protection must be coordinated primarily on the backbone [Mardensyah, Adrial. 2008]. Along with the increasing load and also the age of equipment that is getting old, then setting protection can be less accurate. To be able to ensure the setting of protection relay is required calculation in accordance with the conditions of equipment installed and the current load. Therefore the research is done.

\subsection{High Voltage Transmission Protection}

The power network was divided into the power plant, transmission line, and distribution networks, as shown in Figure 1. 


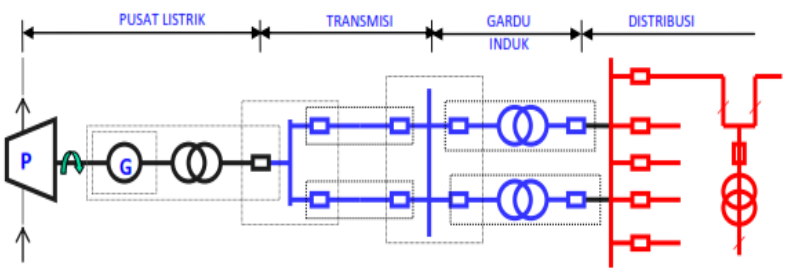

Fig. 1. Power system Network (PT PLN, 2014).

To improve the reliability of the supply of electrical energy, the needed for adequate protection systems is inevitable. Furthermore, a protection system must be able to work optimally. Protection System Transmission consists of primary protection and backup protection as follows [Priyono, Sugeng, 2011]:

- Relay for main protection

- Distance Relay (Basics or Step, PUTT, POTT, Blocking)

- Differential Relay (Pilot, Current, Phase)

- Directional Comparison Relay (Impedance, Current, Super Imposed)

- Backup protection is as follows:

- Local reserve protection system: OCR \& GFR

- Remote backup protection system: Zone 2 .

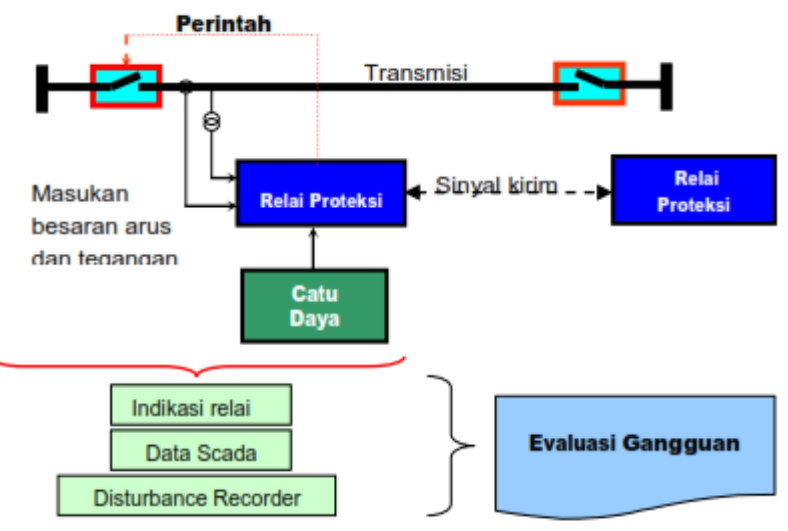

Fig. 2. Block Diagram Protection Transmission (PT PLN, 2014).

\subsection{Power Protection System Components}

Electrical power protection systems generally consist of several components designed to identify the condition of the electrical power system and work-based information obtained from the system such as current, voltage, and phase angle. Information obtained from the electrical power system will be used to compare the magnitude of the threshold setting on the protection equipment. If the amount obtained from the system exceeds the threshold setting of the protection equipment, then the protection system will work.

Equipment protection generally consists of several elements designed to observe the condition of the system. [Stanley H. Horowitz and Arun G. Phadke 2014]

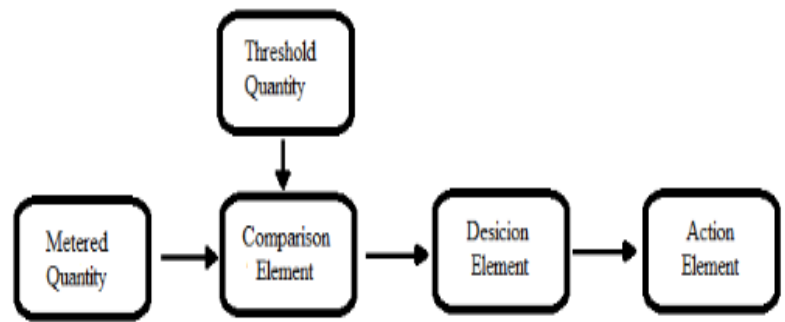

Fig. 3. Electrical Power System Protection Element (PT PLN, 2014).

\subsection{Characteristics of Distance Relay}

Distance relays can be classified by impedance characteristics $(\mathrm{R}-\mathrm{X})$ in polar coordinates, the number of input relay, and the methods used to compare those inputs. Generally, the method used is to compare two inputs to determine whether the disturbance that occurs is inside or outside the work area relay. Distance relay has several work characteristics, including [Antonius dan Fikriansyah. 2014]:

\subsubsection{Characteristics of Mho}

In the $\mathrm{R}-\mathrm{X}$ impedance diagram is a circle with the diameter of the circle intersects the center point of the coordinate system; the magnitude of the diameter represents the range and phase angle settings of the mho characteristic. After the range and phase angle set the same as the impedance of the protected transmission line. This distance relay will work if the measured impedance is inside the circle.

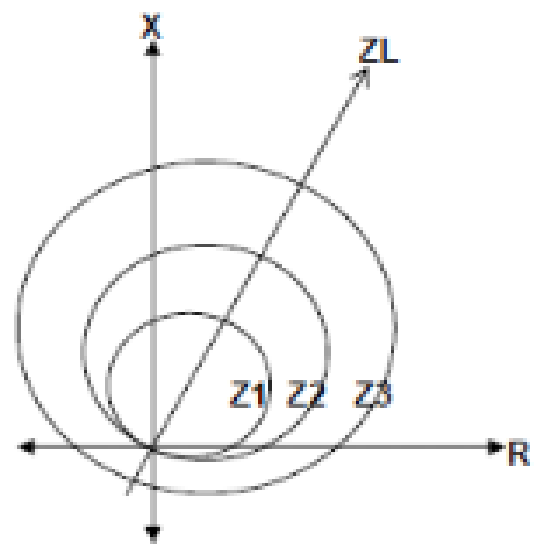

Fig. 4. The working of Mho Characteristics

\subsubsection{Characteristics of quadrilateral}

The characteristics of quadrilateral work can be established by determining the forward reach and resistive reach settings that can be set independently. Figure 4 shows the four sets of limits or range of quadrilateral working characteristics. Four release boundary setting i.e. the upper limit shows the range of reactance range, then the left and right borders are positive resistance settings and the negative resistance as well as the lower border shows the directional element. 


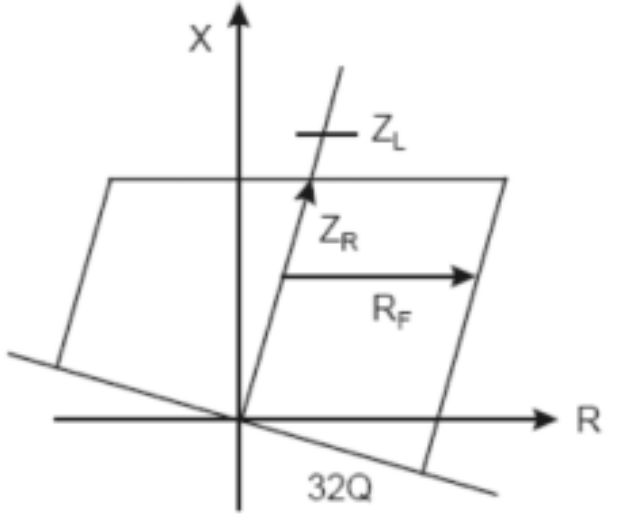

Fig. 5. Characteristics of Quadrilateral

\subsubsection{Security pattern teleprotection distance relay}

In order to improve the coordination of the protection system's time on the high-voltage transmission, a device that can send and receive signals from one or more releases in Station to relay in other Station is required. Protective release equipment is an equipment that can send and receive signals from one release to another. If the distance between one Station with another Station is far enough then needed a communication medium that can be used to send a signal. The communication channel used can be an optical fiber, Power Line Communication (PLC) or through the microwave.[ Sunil S. Rao].

The security patterns used in the distance relay include:

- Direct Underreach Transfer Trip (DUTT)

For the DUTT pattern logic, the circuit scheme can be shown in Figure 5.

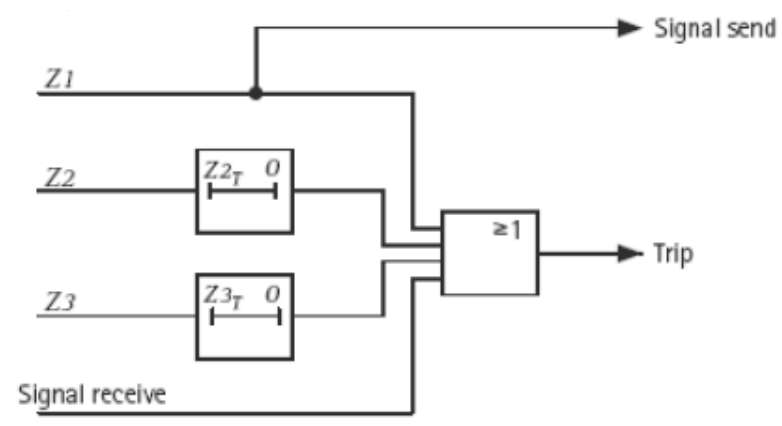

Fig. 6. Logic circuits direct underreach transfer trip

- Permissive Underreach Transfer Trip (PUTT)

The working principle of the PUTT pattern is: if the disturbance felt at the one release distance zone, the relay will send a trip signal to $\mathrm{CB}$. At the same time, it sends a signal to the relay at the other terminal.

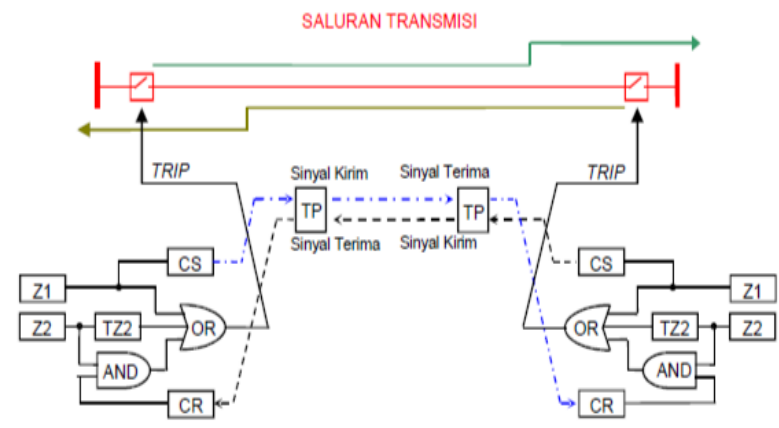

Fig. 7. Logic circuits PUTT scheme

- Permissive Overreach Transfer Trip (POTT)

The working principle of the POTT pattern is that if there is a disturbance felt by the two-distance relay zone, the relay will send the signal to the other end terminals and the other ends of the terminals will only work if the interference is also felt by the two relay. The logic drawing circuit is shown in Figure 7.

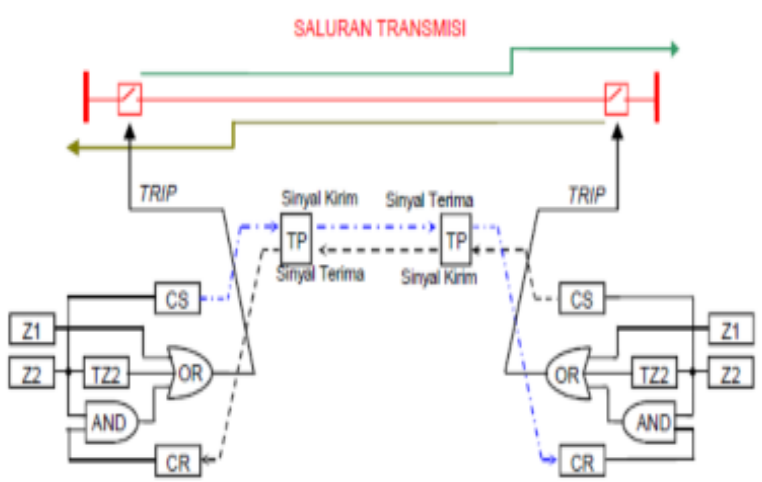

Fig. 8. Permissive overreach transfer trip

- Blocking scheme

In this pattern, tele-protection equipment will send a signal to the TP equipment on the substation in front of it if the distance relay detects the disturbance at the back. Then the relay will give an instantaneous trip command, the rule shown in Figure 9.

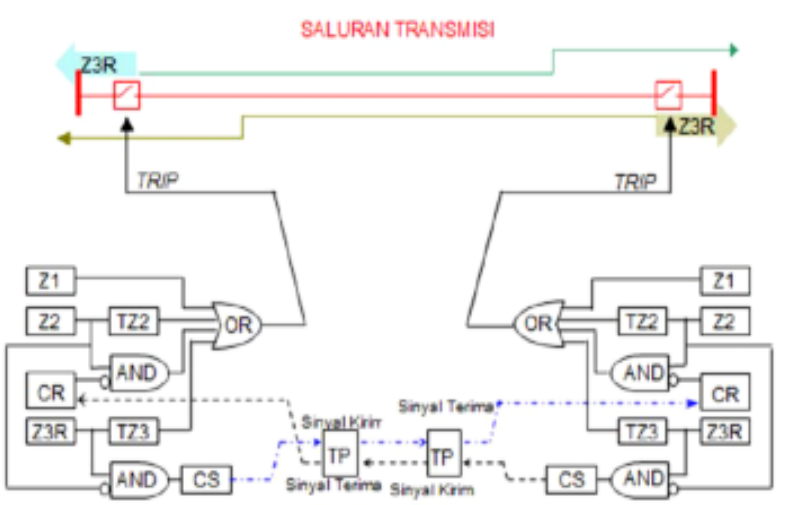

Fig. 9. Logic circuits of blocking

\subsection{Over Current Relay (OCR)}

Protection systems in high-voltage transmission use more OCR and GFR as a local back up protection. OCR is a relay that works when the current exceeds the 
predetermined setting thresholds. OCR has some working characteristics [PT. PLN (Persero). 2010. SPLN T5.002$1 / 2010]$.
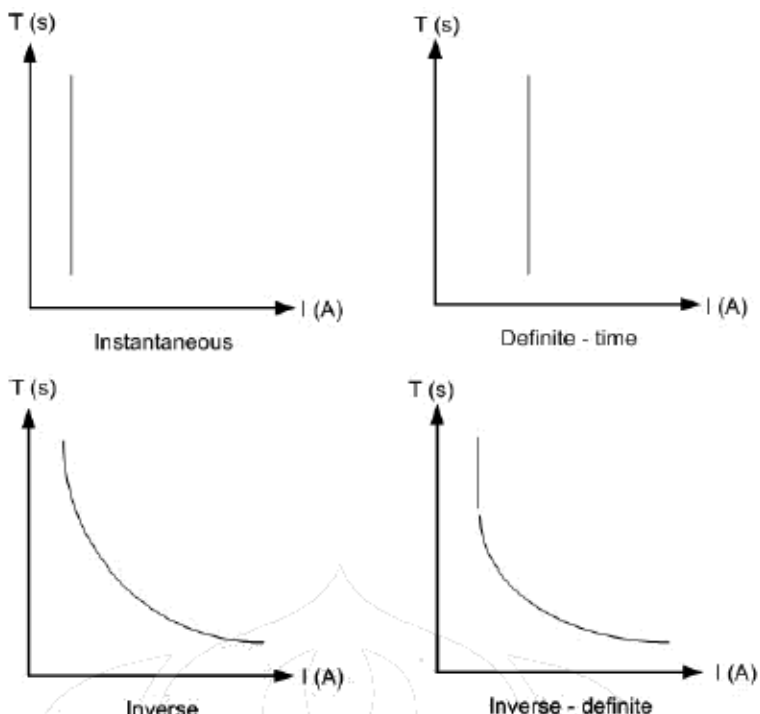

Fig. 10. Characteristics of OCR

$$
\begin{gathered}
T_{\mathrm{OCR}}=1 \mathrm{sec} \\
T M S=\left[\left(\frac{I_{3 s c}}{I_{\text {set }}}\right)^{0.02}-1\right] \frac{T}{0.14} \\
T M S=\left[\left(\frac{19939}{817}\right)^{0.02}-1\right] \frac{T}{0.14} \\
T M S=0.47
\end{gathered}
$$

\subsection{Ground Fault Relay (GFR)}

The fault of the ground is one of the most common disturbances in transmission lines; this is because the transmission is used using air insulation, so it is very susceptible to soil disturbance. To detect any current flowing from the system to the ground or also called the residual current.

$\mathrm{IR}=\mathrm{IA}+\mathrm{IB}+\mathrm{IC} ; \quad \mathrm{IR}=$ Residual current

GFR is a working relay based on the amount of residual current flowing from the system. The following figure 11 shows the measurement of the residual current from the three-phase system [Haskarya, Henry, 2016].

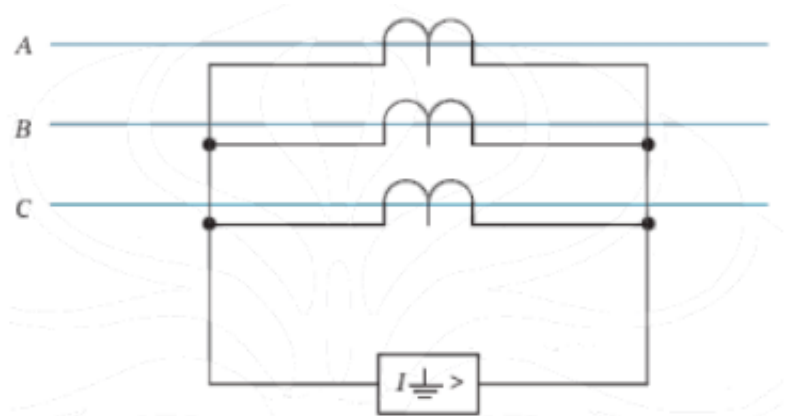

Fig. 11. Residue current measurement scheme

\section{Method}

The type of research is a case study which aims to coordination study of protective releases for high-voltage transmission Substation of Payakumbuh - Koto Panjang. Network Transmission $150 \mathrm{kV}$ Koto Panjang Payakumbuh consists of 248 towers, two transmission lines, and two ground wires with a total length of 84.844 km (169,688 kms) [PT PLN (Persero), 2014, KEPDIR 0520-3].

1. Equipment data

a. Specifications of protection relay

b. Ratio CT and PT

c. Impedance, ratio, and capacity of power transformer

d. Impedance or transmission line impedance

2. Power system configuration

The configuration of the electric power system used to coordinate the protective relay protection settings on high-voltage Transmission is a $150 \mathrm{kV}$ system configuration of the Sumbagteng System as of April 2017. 3. Short circuit current

The short circuit current calculation for the coordination of the settings OCR and the GFR on the transmission line is done using the help of the software application DigSillent Power Factory version 15.1 assuming the configuration of the system conditions under normal operating conditions by 2017.

\subsection{Data Required}

Method of calculation/ data analysis is done with the steps as follows:

1. Calculate the value of channel impedance $150 \mathrm{kV}$ Transmission Station Payakumbuh-Koto Panjang

2. Calculate the value of setting relays, OCR, and GFR for the $150 \mathrm{kV}$ Transmission Payakumbuh-Koto Panjang

Calculation distance relay coordination, OCR, and GFR for $150 \mathrm{kV}$ Transmission Payakumbuh - Koto Panjang.

\subsection{Trasmission Impedance Data $150 \mathrm{kV}$}

The data of high-voltage transmission impedance and channel length was used for calculation of distance relays

\begin{tabular}{|c|c|c|c|c|}
\hline $\begin{array}{c}\text { SUTT } \\
150 \text { kV }\end{array}$ & $\begin{array}{c}\text { Type of } \\
\text { Conductor }\end{array}$ & $\begin{array}{l}\text { Electric } \\
\text { Current }\end{array}$ & $\begin{array}{c}\text { Chann } \\
\text { el } \\
\text { Length }\end{array}$ & $\begin{array}{c}\text { Channel } \\
\text { Impedance } \\
(/ \mathbf{k m})\end{array}$ \\
\hline $\begin{array}{c}\text { Pyk - } \\
\text { Koto Pjg }\end{array}$ & $\begin{array}{c}\text { ACSR } \\
\text { HAWK } \\
1 \times 330 \mathrm{~mm}^{2}\end{array}$ & $\begin{array}{l}790 \\
\text { Amp }\end{array}$ & $\begin{array}{c}85.11 \\
\mathrm{~km}\end{array}$ & $\begin{array}{c}0.09805+ \\
\mathrm{j} 0.41606 \Omega\end{array}$ \\
\hline $\begin{array}{c}\text { Pyk- } \\
\text { Batu } \\
\text { sangkar }\end{array}$ & $\begin{array}{c}\text { ACSR } \\
\text { HAWK } \\
1 \times 340 \mathrm{~mm}^{2}\end{array}$ & $\begin{array}{c}790 \\
\text { Amp }\end{array}$ & $\begin{array}{c}26.19 \\
\mathrm{~km}\end{array}$ & $\begin{array}{r}0.09356+ \\
\mathrm{j} 0.41790 \Omega\end{array}$ \\
\hline $\begin{array}{c}\text { Pyk - } \\
\text { Pdg Luar }\end{array}$ & $\begin{array}{c}\text { ACSR } \\
1 \times 240 \mathrm{~mm}^{2}\end{array}$ & $\begin{array}{l}645 \\
\text { Amp }\end{array}$ & $\begin{array}{c}32.18 \\
\mathrm{~km}\end{array}$ & $\begin{array}{c}0.12745+ \\
\mathrm{j} 0.42397 \Omega\end{array}$ \\
\hline Koto Pjg & $\begin{array}{c}\text { ACSR } \\
1 \times 435 \mathrm{~mm}^{2}\end{array}$ & $\begin{array}{c}940 \\
\text { Amp }\end{array}$ & $\begin{array}{c}17.91 \\
\mathrm{~km}\end{array}$ & $\begin{array}{r}0.07260+ \\
j 0.39117 \Omega\end{array}$ \\
\hline
\end{tabular}
protection settings based on the data obtained from P3B Sumatera.

Table 1. Data of impedance transmission $150 \mathrm{kV}$. 


\begin{tabular}{|c|c|c|c|c|}
\hline $\begin{array}{c}\text { Bangkina } \\
\text { ng }\end{array}$ & & & & \\
\hline $\begin{array}{c}\text { Koto Pjg } \\
\text { - Garuda } \\
\text { Sakti }\end{array}$ & $\begin{array}{c}\text { ACSR } \\
1 \times 435 \mathrm{~mm}^{2}\end{array}$ & $\begin{array}{c}940 \\
\text { Amp }\end{array}$ & $\begin{array}{c}64.01 \\
\mathrm{~km}\end{array}$ & $\begin{array}{c}0.07260+ \\
\mathrm{j} 0.39117 \Omega\end{array}$ \\
\hline
\end{tabular}

In doing the analysis and calculation used formulas given on the theoretical basis and as a validation calculation used software DigSILLENT Power Factory version 15.1.

\section{Results and Discussion}

The simulation was used to see the maximum short circuit current using the Calculation Short Circuit menu. The maximum short-circuited current is a short-circuit current which is the number of incoming/ sync generating units with the maximum Sumbagteng system. The assumptions used in assisting these calculations are:

a. The impedance used is $0.1 \mathrm{Ohm}$ for resistance and 0 Ohm for reactance.

b. Short circuit duration:

1. Breaker Time: 60 milliseconds

2. Fault Clearing Time: 120 milliseconds according to SPLN No. 52-1 Year 1984

c. Short circuit interruption simulated on high voltage Transmission connecting Station Payakumbuh - Koto Panjang.

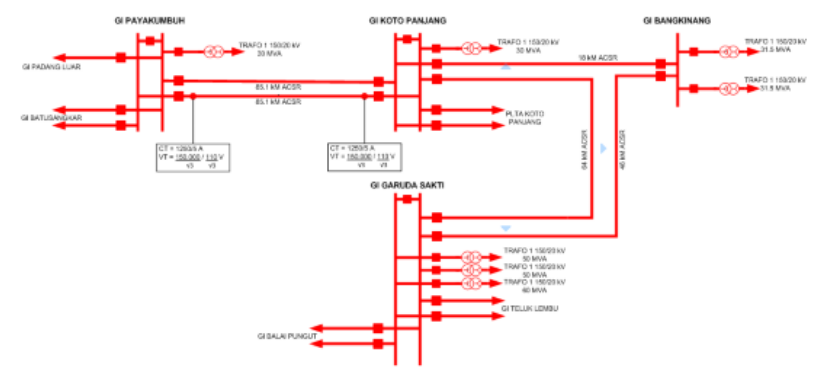

Fig. 12. The diagram one line on Payakumbuh - Koto Panjang Station (PT PLN, 2014).

\subsection{Setting Relay Protection Transmission 150 kV Payakumbuh - Koto Panjang Station}

\subsubsection{Calculation of OCR}

The calculation of relay protection settings was done by manually calculate based on the completeness of the data obtained.

Table 2. Calculation of OCR $150 \mathrm{kV}$ Transmission Payakumbuh - Koto Panjang.

\begin{tabular}{|c|c|c|}
\hline $\begin{array}{c}\text { Basic } \\
\text { Calculation }\end{array}$ & I $_{\text {set }}$ & TMS \\
\hline $\begin{array}{c}\text { Current } \\
\text { Setting }\end{array}$ & $900 \mathrm{Amp}$ & 0.325 \\
\hline
\end{tabular}

\begin{tabular}{|c|c|c|}
\hline Using CCC & $948 \mathrm{Amp}$ & 0.45 \\
\hline $\begin{array}{c}\text { Using } \\
\mathrm{CT}_{\text {primer }}\end{array}$ & $1500 \mathrm{Amp}$ & 0.38 \\
\hline $\begin{array}{c}\text { Highest } \\
\text { Load }\end{array}$ & $817 \mathrm{Amp}$ & 0.47 \\
\hline
\end{tabular}

Based on the simulation of a three-phase short circuit in DigSILLENT Power Factory version 15.1 application obtained OCR setting characteristics as follows:

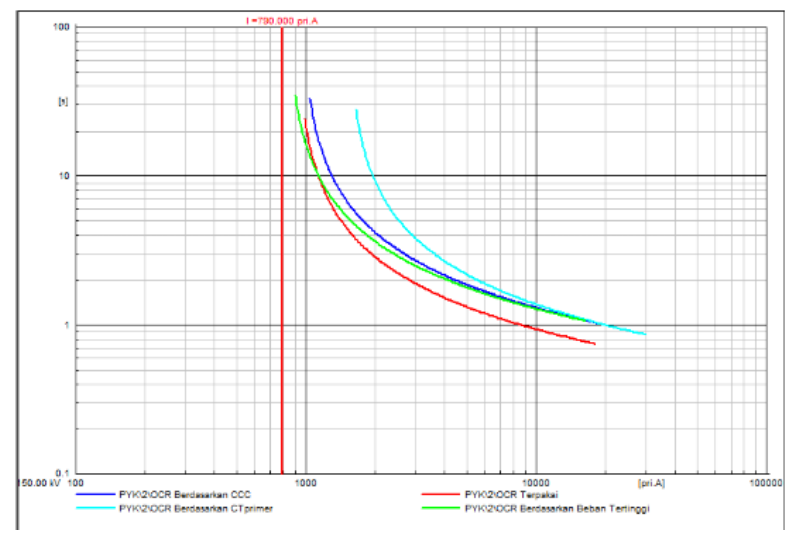

Fig. 13. Characteristics of OCR calculation transmission $150 \mathrm{kV}$ Payakumbuh - Koto Panjang.

Figure 13 shows the characteristics of OCR setting calculation Transmission $150 \mathrm{kV}$ Payakumbuh - Koto Panjang. The current setting is sufficiently low so that the possibility of conducting trips due to more load will be easy to happen, as well as setting if we use the highest load data ever achieved; this causes the carrier capability to be lower than the ability to deliver the maximum current he has. However, if the setting used based on the primary CT was used, this value is too high. So it can damage the equipment; especially it can cause the conductor to overheat which is very risky if it left. So the most optimal setting is the setting using the lowest equipment capabilities. In this case, delivery capability or known as CCC (Current Carrying Capacity). This setting is not too low or not too high and safe for all equipment.

\subsubsection{Calculation of GFR}

$\begin{array}{ll}\text { Merk Relay } & : \text { Siemens Reyrolle } \\ \text { Type } & : \text { 7SR11 } \\ \text { Conductor } & : \text { ACSR HAWK 1x330 mm2CCC }=790 \\ \text { Characteristic } & : \text { Standard Inverse - IEC } \\ \text { Setting of GFR } & \text { installed: } \\ \text { Setting } & : 0.10^{*} \text { In Amp td / t : 0.550 (SI-IEC) } \\ \text { Inst. } & : \text { Block* In Amp } \\ \text { td } / \mathrm{t} & : \text { Block }(\text { Definite }) \\ \text { Ratio CT } & =1250 / 5 \\ \text { Ampere, In } & =5 \text { Ampere }\end{array}$

Based on DigSILLENT simulation result for a single phase short circuit to ground at $150 \mathrm{kV}$ Station Payakumbuh to Koto Panjang, it obtained maximum short circuit current: $I \mathrm{~s}=3493$ A. 
Table 3. Calculation of GFR $150 \mathrm{kV}$ Transmission Payakumbuh - Koto Panjang.

\begin{tabular}{|c|c|c|}
\hline $\begin{array}{c}\text { Basic } \\
\text { Calculation }\end{array}$ & $\mathbf{I}_{\text {set }}$ & TMS \\
\hline $\begin{array}{c}\text { Current } \\
\text { Setting }\end{array}$ & $125 \mathrm{Amp}$ & 0.55 \\
\hline Using CCC & $158 \mathrm{Amp}$ & 0.46 \\
\hline $\begin{array}{c}\text { Using } \\
\mathrm{CT}_{\text {primer }}\end{array}$ & $250 \mathrm{Amp}$ & 0.39 \\
\hline $\begin{array}{c}\text { Highest } \\
\text { Load }\end{array}$ & $136 \mathrm{Amp}$ & 0.48 \\
\hline
\end{tabular}

Based on the simulation of short circuit 1 phase to the ground in DigSILLENT Power Factory application version 15.1, it got characteristic of GFR release setting as follows:

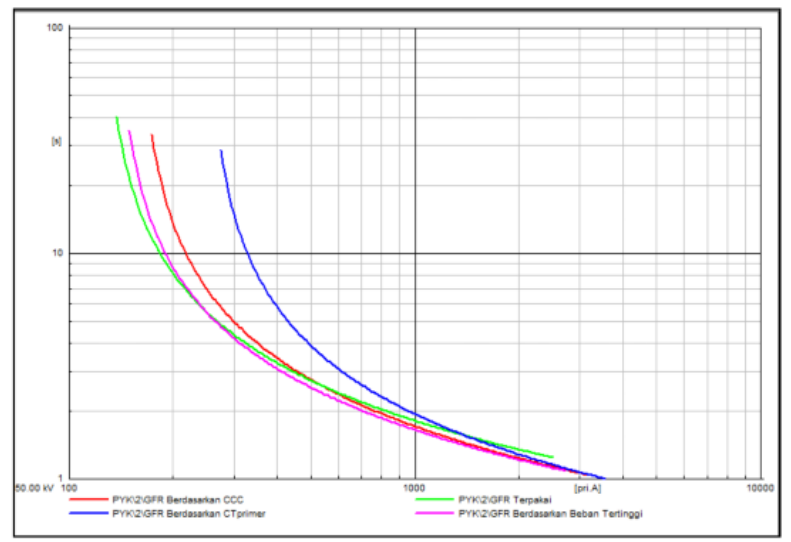

Fig. 14. Characteristics of GFR calculation transmission $150 \mathrm{kV}$ Payakumbuh - Koto Panjang.

Figure 14 shows the characteristics of GFR Transmission 150 kV Payakumbuh - Koto Panjang. The current setting is quite low; this is a bit risky because there is a possibility of trip GFR in the transformer or a malfunctioning relay, as well as calculations based on the highest load setting, is also quite low. But, if we use the setting based on the primary $\mathrm{CT}$, the setting is too high, so the releases are inaccurate in detecting interference. Then the most optimal setting is the setting using the lowest equipment capabilities, in this case, the delivery capability or known as CCC (Current Carrying Capacity). This setting is considered quite optimal and can maintain the security and lifetime of all equipment.

\subsection{Setting Distance Relay of Payakumbuh - Koto Panjang Station}

Time Delay : $\quad \mathrm{T} 1=0.00 \mathrm{sec}$

$\mathrm{T} 2=0.40 \mathrm{sec}$

$\mathrm{T} 3=1.20 \mathrm{sec}$

Table 4. Data distance relay.

\begin{tabular}{|l|l|}
\hline Mode & Value \\
\hline
\end{tabular}

\begin{tabular}{|c|c|}
\hline Program Mode & $\begin{array}{c}\text { Standard } \\
\text { Scheme }\end{array}$ \\
\hline Standard Mode & PUP Z2 \\
\hline Fault Type & Both Enabled \\
\hline Trip Mode & $\begin{array}{c}1 \mathrm{P}, \mathrm{Z1} \mathrm{Z2} \mathrm{\&} \\
\mathrm{CR}\end{array}$ \\
\hline $\begin{array}{c}\text { tReserval Guard } \\
46.00 \mathrm{~ms}\end{array}$ \\
\hline $\begin{array}{c}\text { Unblocking } \\
\text { Logic }\end{array}$ & None \\
\hline $\begin{array}{c}\text { SOTF/TOR } \\
\text { Mode* }\end{array}$ & $\begin{array}{c}00000100010 \\
000\end{array}$ \\
\hline $\begin{array}{c}\text { SOTF Delay } \\
10 \mathrm{~s}\end{array}$ \\
\hline ZIExt Fail & Disabled \\
\hline
\end{tabular}

Based on recalculation of distance relay setting for high voltage air transmission line at $150 \mathrm{kV}$ carrier from Station Payakumbuh to Koto Panjang, the characteristics of distance releasing work as seen in the picture below (based on DigSILLENT Power Factory simulation):

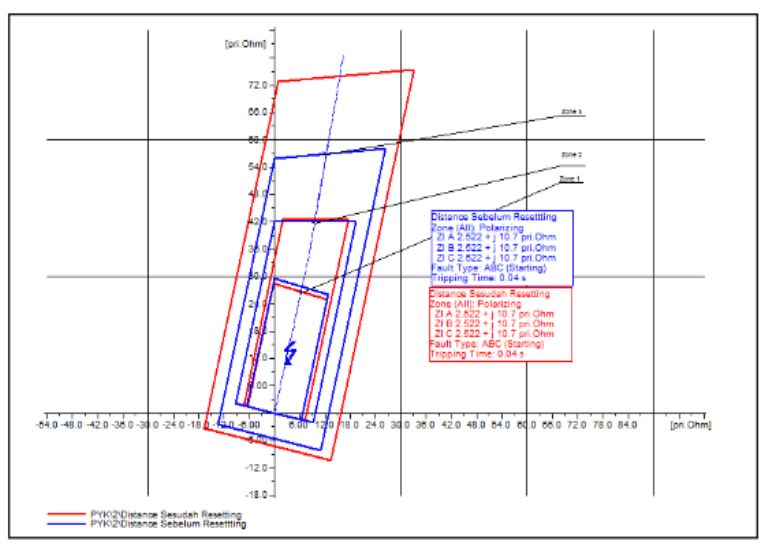

Fig. 15. The work characteristics of distance relay transmission 150 kV Payakumbuh - Koto Panjang.

\section{Conclusion and recommandations}

1. To anticipate the failure of the relay release operation, it uses more relay current and ground disturbance as protection of local reserve at high voltage air channel with delay time set more than delay zone two releases. Based on the calculation and analysis of relay settings OCR, GFR and Distance it can be concluded as follows:

Here is the coordination of more OCR and GFR:

OCR TMS $=0.45(\mathrm{~T}=1 \mathrm{sec})$

GFR TMS $=0.63(\mathrm{~T}=1 \mathrm{sec})$

2. By calculating the error factor on the distance release protection as the main safeguard as well as the remote 
backup guard for the high-voltage $150 \mathrm{kV}$ Transmission of Payakumbuh - Koto Panjang channel which has a channel length of $85.11 \mathrm{~km}$, the coordinate of the settings obtained is:

Phase Fault

Zona $1=68.08 \mathrm{kM}(\mathrm{T}=0.0 \mathrm{sec})$,

Zona $2=101.02 k M(\mathrm{~T}=0.4 \mathrm{sec})$,

Zona $3=173.68 k M(\mathrm{~T}=1.2 \mathrm{sec})$,

Ground Fault

Zona $1=2.57+\mathrm{j} 5.18 \Omega(\mathrm{T}=0.0 \mathrm{sec})$,

Zona $2=4.00+\mathrm{j} 7.77 \Omega(\mathrm{T}=0.4 \mathrm{sec})$,

Zona $3=5.48+\mathrm{j} 13.27 \Omega(\mathrm{T}=1.2 \mathrm{sec})$.

3. For temporary disturbances, the distances relay can be coordinated auto reclosing which works to close the breaker automatically. The auto reclosing relay coordination setting used is: Dead Time $=1 \mathrm{sec}$ and Reclaim Time $=40 \mathrm{sec}$.

\section{References}

1. A. Arismunandar, S. Kuwahara, Electric power engineering 3, (Pradnya Paramita, Jakarta, 2004)

2. M. Adrial, Coordination study of relay protected relocation at high voltage of substation Gambir Lama - Pulomas, (Indonesia University, 2008)

3. Nugroho, A. Setyo, Distance relay coordination, over current relay and ground foult relay against resistive short circuit interruption (Diponogoro University, 2011)

4. Priyono, Sugeng, Koordinasi sistem proteksi trafo 30 MVA di Gardu Induk 150kV Krapyak (2011)

5. PT PLN (Persero), KEPDIR 0520-3 guidance of maintenance of protection and delivery control (Jakarta, 2014)

6. E. Supriyadi, Electrical protection system (Adicipta Karya Nusa Jakarta, 2005)

7. S. S. Rao, Switchgear and protection, $10^{\text {th }}$ Edition, KHANNA Publishers, (Delhi, 1994)

8. A.M.A.E. Aleem, Design and Implementation of AProgrammable Simulation for the Estimation of the Over currentProtection Relays Immunity Against Decaying DC offset, M.Sc. Dissertation (Office of Graduate Studies of Cairo University, 2007)

9. S. H. Horowitz, A. G. Phadke, Power system relaying, $4^{\text {th }}$ Edition John Wiley \& Sons, Ltd. (2014)

10. K. Kasinathan, Power system fault detection and classification using wavelet transforms and adaptive resonance theory neural networks, M. Sc. Dissertation (Office of Graduate Studies of Kentucky University, 2006)

11. S.H. Horowitz, A.G. Phadke, Power system relaying, $3^{\text {rd }}$ Edition, Research Studies Press Limited (England, 2008)

12. B.R. Bhalja, R.P. Maheshwari, High-resistance faults on two terminal parallel transmission line: analysis, simulation studies, and an adaptive distance relaying scheme, IEEE transactions on power delivery 22 (2) (2007)

13. Anharul, Eddy, Coordinate relay on transmission network 150kV, J. JomFTEKNIK 3 (2) (Riau, 2016)

14. Antonius, Fikriansyah, Analysis and rearranging of distance relays on high voltage transmission line 150 kV Keramasan - Bukit Asam, Mikrotiga 1 (3) (Palembang, 2014)

15. H. Henry, Coordination of SUTT protection in GIM liwang-tuban consequences addition of power plant steering Tanjung Awar-Awar. J. Teknik ITS 52 (Surabaya, 2016)

16. PT. PLN (Persero), Pattern of transmission line protection section 1 height voltage $66 \mathrm{kV}$ dan $150 \mathrm{kV}$ (2010)

17. Sugiyantoro, Bambang, Effect of arc resistance on relay performance distance on transmission $150 \mathrm{kV}$, CITEE (Jogjakarta, 2017) 